\title{
Invoking the Supervisory Jurisdiction of the Supreme Court of Ghana. The Case of a Meddlesome Interloper (Busybody)
}

\author{
Kwame Yaro Appiah (), Kwame Richard Klu \\ African Centre for SDGs Research and Policy, Accra, Ghana \\ Email: africansdgscentre@gmail.com
}

How to cite this paper: Appiah, K. Y., \& Klu, K. R. (2021). Invoking the Supervisory Jurisdiction of the Supreme Court of Ghana. The Case of a Meddlesome Interloper (Busybody). Beijing Law Review, 12, 1179-1190. https://doi.org/10.4236/blr.2021.124061

Received: October 21, 2021

Accepted: December 12, 2021

Published: December 15, 2021

Copyright $\odot 2021$ by author(s) and Scientific Research Publishing Inc. This work is licensed under the Creative Commons Attribution International License (CC BY 4.0).

http://creativecommons.org/licenses/by/4.0/

\begin{abstract}
The Ghanaian courts have allowed the efflorescence of legal doctrines as necessary nutrients for the enjoyment and development of rights and obligations under the law within the Ghanaian jurisdiction. One such procedural doctrine is LOCUS STANDI or capacity of a party to invoke the supervisory jurisdiction of the Supreme Court of Ghana. This allows the Supreme Court to exercise constitutional oversight responsibility over the actions of all other courts in Ghana. This power emanates from Article 132 of the 1992 Constitution of the Republic of Ghana. The aim of this research is to unravel the inconsistency with which the Supreme Court of Ghana deals with who has the capacity under Article 132 to access the Supervisory Jurisdiction of the Supreme Court of Ghana under Constitutional regime. This paper was developed through qualitative review of various literatures and relevant modern case law to the subject.
\end{abstract}

\section{Keywords}

LOCUS STANDI, Capacity, Supervisory Jurisdiction, Supreme Court, High Court, Constitution, Wednesbury Principle, Judicial Review, Jurisprudence, Ex Parte

\section{Introduction}

Since the evolution of the Courts (Barrett, 2006) as bastions of the protection and enforcement of justice, controversies have never subsided over the relevance of their existence in regards to citizenry access to the powers that lie within. One such hotly debated power of the courts is the Supervisory jurisdiction, its genesis and revelations, thus the Supervisory jurisdiction of the Supreme Court of Gha- 
na, the apex court within the Ghanaian jurisdiction. Supervisory jurisdiction organically refers to general superintendence of Superior courts over subordinate courts. The object of the development of the supervisory jurisdiction as a premise of exercise of the powers of the Superior courts is to keep subordinate courts within their prescribed sphere, thus prevention of the situation of jurisdictional usurpation, the dose for miscarriage of justice (Dickerson v. United States, 2000). It allows for the exercise of such control to ensure the issue of necessary and appropriate writs. In other common law jurisdictions such as the United States, the law in this area is clear, superior courts have supervisory authority over the federal courts, and such may be used to prescribe rules of evidence and procedure that are binding on tribunals. The prescription of this power is not a problem within the Ghanaian legal system but the scope of exercise as revealed by the courts from legal year to legal year culminating in the invocation which recently in the 2019-2020 legal year has surfaced as grave inconsistency to the regular precedence. This aroused utmost critique of the legal unpredictability of the Ghanaian law. In contributing to the scope of the discussion, the definite question to ask is who has LOCUS STANDI or is clothed with capacity to access the Supervisory Jurisdiction of the Supreme Court of Ghana under Article 132 of the Constitution of Ghana? The earlier courts of 1963-1964 legal years omit non-interest holders; busybodies from having capacity under Article 132. The courts of the 1991-1992 legal year took a swipe decision stating that third non-interest holders thus busybodies have accrued right under through Article 2(1) to petition the Supreme Court of Ghana to supervise the action of other courts. The 2003-2004 legal year reverted to the 1963-1964 position which stated that only persons with direct interests in matters could sue to access the supervisory jurisdiction of the Ghanaian Supreme Court. The courts again in the 2005-2006 revised capacity requirements for invoking the supervisory jurisdiction of the Supreme Court to that held in 1963-1964. This was sustained reversed in 2010-2011 legal year. In the 2015-2016 legal year to 2016-2017, the court sustained that capacity under article 132 does not warrant direct interest. The courts reversed again in 2018-2019 that a person has capacity under Article 132 to invoke the supervisory jurisdiction of the Supreme Court when said person has direct interest in the matter. This back and forth hath matured a situation that best invokes the catholic aphorism; when the benediction seems longer than the mass. This paper will analyse the phenomenon and advocate for legal precision and predictability. It will carry out this exercise through precedence analysis.

\section{Article 132 and Its Essence}

The Supreme Court of Ghana has through the ancient practice of codification been gifted as a supervisory body within the court system of Ghana through article 132. This supervisory jurisdiction of the Supreme Court extends to all courts below the rank of the Supreme courts (including the High Court) and any 
adjudicating authorities. The supervisory jurisdiction is constitutionally hinged on the principle of judicial review. Judicial review is the process where the courts declare the enactment of the legislature as constitutional or haven been exercised within the frame of the intention of the lawmaker (Kumado, 1977). In the exercise of such powers, the Supreme Court may issue orders and directions for the purpose of enforcing or securing the enforcement of its supervisory power as provided under Article 132 of the 1992 Constitution. A special case for the exercise of the supervisory jurisdiction of the Supreme court is when in the wisdom of the Supreme Court, the High Court in exercising its jurisdiction (See Article 140 of the 1992 Constitution), breaches the rules of natural justice or on the face of its orders it substantially errs in law, or has acted in excess of its jurisdiction or acted without jurisdiction in a matter under its powers. Any circumstance within the precincts of the above scenarios inures to the Supreme Court the authority to order submission of such proceedings before it for the purpose of having them quashed. Other legal systems also have a similar case where Federal courts are reposed with constitutional powers to supervise the actions of State courts. This is notorious of the Nigerian legal system (Odike \& Akujobi, 2018). In view of article 132 of the 1992 Constitution of Ghana, judicial notice has been taken of the circumstances that arouse the exercise of the Supervisory jurisdiction of the Supreme Court. This include (i) Want or excess of jurisdiction; (ii) Error of law on face of the record; (iii) Failure to comply with the rules of natural justice and finally; and (iv) On the Wednesbury Principle.

\section{Ghanaian Jurisprudence}

The grounds in (i), (ii), (iii) and (iv) have been echoed by an avalanche of Ghanaian jurisprudence (Republic V High Court, Kumasi; Ex Parte Appiah And Ors). These authoritative decisions include but not limited the following REPUBLIC v. COMMITTEE OF INQUIRY INTO NUNGUA TRADITIONAL COUNCIL AFFAIRS; EXPARTE ODAI 1V. In this case, the court held that for right to judicial review to adduce to a plaintiff, there must be grave error of law on the surface of the law record. In THE REPUBLIC v. HIGH COURT, ACCRA; EX-PARTE CHRAJ (ADDO INTERESTED PARTY) the court held that judicial review by invocation of the supervisory jurisdiction of the Supreme Court of Ghana is only accessible when there is want or excess of jurisdiction. Also, in REPUBLIC v. HIGH COURT, KUMASI; EX-PARTE BANK OF GHANA (NO. 1) the court held that failure to comply with the rules of natural justice is a ground on which capacity could be assumed to seek judicial review of the Supreme Court over decisions of other courts. The Wednesbury Principle was also given notoriety in the case of THE REPUBLIC v. COURT OF APPEAL; EX-PARTE TSATSU TSIKATA as a ground on which capacity could be assumed for judicial review at the Supreme Court. The Wednesbury Principle relates to a situation where the decision of a court or adjudicatory body is so unreasonable that no reasonable person acting reasonably could have made it. In 
EX-PARTE TSATSU TSIKATA, the Supreme Court speaking through Wood, JSC (as she then was) at page 619 gifted as that:

"The clear thinking of this Court is that, our supervisory jurisdiction under article 132 of the 1992 Constitution, should be exercised only in those manifestly plain and obvious cases, where there are patent errors of law on the face of the record, which errors either go to jurisdiction or are so plain as to make the impugned decision a complete nullity. It stands to reason then that the error(s) of law alleged must be fundamental, substantial, material, grave or so serious as to go to the root of the matter. The error of law must be one on which the decision depends. A minor, trifling, inconsequential or unimportant error, or for that matter an error which does not go to the core or root of the decision complained of, or stated differently, on which the decision does not turn, would not attract the court's supervisory intervention".

Also in REPUBLIC V. HIGH COURT, EX-PARTE SOSU, the court held that "An applicant may succeed in invoking the Supreme Court's supervisory intervention upon demonstrating that the High Court wrongly assumed jurisdiction in the matter which was patent on the face of the record. The error must be so grave as to amount to the wrong assumption of jurisdiction. The error must be obvious as to make the decision a nullity."

It must be noted that by Judicial Review (See Republic v. Court of Appeal, Accra; Ex parte: Tsatsu Tsikata), the exercise of supervisory jurisdiction of the Supreme Court is pinched on procedural laws on which the subordinate court exercised its powers. The law of Article 132 is not a substantive law (The Republic v. High Court, General Jurisdiction; Ex Parte Attorney General; Interested Party Exton Cubic). The court does not exercise this power as a means of further adjudication. It is important to point out here that, the supervisory jurisdiction of the Court is not a forum for appealing a case in dispute, since Judicial Review and Appeal are in law conceptually different and should always be recognized as such. Appeal is an application to a higher appellate court to correct an error which may be legal or factual. In Ghana, all Civil Appeals are by way of rehearing (Brown v. Quashigah at 941) and the appellate court may subject the whole record to review and may even make new findings of facts in deciding the appeal.

\section{Capacity Requirement}

The most important reason for this paper is to draw attention to the sorrowful state of the law in regards to capacity under Article $\mathbf{1 3 2}$ as at today. This is to say that, the determination of capacity to invoke the supervisory jurisdiction of the Supreme Court under Article 132 of the Constitution hath seen a downward trend in its applicability which stands against modern global developments of law, a reasonable conclusion that the non-stable philosophy of the Supreme Court, respectfully, has rather led to the stagnation, unpredictability and a stab to the advocacy fronts for the widening of the concept of justice within the 
Ghanaian legal system. Article 132 (1992 Constitution) capacity issues have been hotly discussed by the court in old and recent decisions of which relevant excepts will be used to highlight this confusion in this paper. The methodology for the selection of case species for this research is largely based on our organisations Case Reverence Ranking. The 1963-1964 legal year, the courts speaking in the case of STATE v. ASANTEHENE'S DIVISIONAL COURT BI; EX PARTE KUSADA held inter alia that:

"An applicant for an order of certiorari must be either a person aggrieved or a person who has a real or substantial interest in the proceedings sought to be quashed."

In 1991-1992, the Court in REPUBLIC v. KORLE GONNO DISTRICT MAGISTRATE GRADE I; EX PARTE AMPOMAH held that capacity under article 132 could be invoked by persons who may come under 2(1) of the Constitution and as such it is not restricted to those whose legal rights would directly be affected. The 2003-2004 legal year saw the reversal of the long-standing capacity position of the courts for article 132 of the Ghanaian constitution. Judicial notice can be taken of the pronouncement of His Lordship, Justice Professor Date-Bah in Republic v. High Court, Denu; Ex parte: Agbesi Awusu II (No. 1), (Nyonyo Agboada (SRI III) Interested Party). He positioned at holding 2, page 867:

"The established rule was that the discretionary remedy of certiorari would generally be granted to any person aggrieved by the order sought to be impugned. By person aggrieved was meant the person directly affected by the order complained of. In real terms, he was the person against whom the order was directed, or whose legal rights had been infringed by the order sought to be impugned or who had any other legally recognisable or substantial interest in impugning the order. The exception to the general rule was that it was only in highly exceptional cases that, that remedy would be extended to an applicant who was not aggrieved".

To this, Professor Date-Bah JSC held that only persons whose rights are directly affected by the case realizing the action through judicial review possess capacity under article 132. The 2005-2006 legal year saw the reversal of the 2003-2004 position to the 1991-1992 court's position on capacity under article 132 of the Constitution in REPUBLIC v HIGH COURT, ACCRA; EX PARTE APPENTENG. This position is that, capacity extends to any person who possesses any rights to trigger an action under article 2(1) and not necessarily the proof of personal interests in the matter of the action on their case. The 2010-2020 decade saw a lot of judicial activism in the sphere of article 132 which is of much relevance to the scope of this discussion. To wit, REPUBLIC v. HIGH COURT, HO, EX PARTE BEDIAKO II \& ANOR (ODUM \& ORS INTERESTED PARTIES is instructive. In this case the worthy president of this court Dotse, JSC after referring to the previous authorities on this point; notably, REPUBLIC $\mathrm{v}$ KORLE GONNO DISTRICT MAGISTRATE GRADE I; EX PARTE AMPOMAH 
and APPENTENG, IN RE (DECD); REPUBLIC v. HIGH COURT, ACCRA; EX PARTE APPENTENG said at page 712 as follows:

"In the instant case, the applicants herein were the complainants in the criminal case which is the genesis of the entire application before this court. In that respect, therefore, the applicants must be deemed to have more than sufficient interest in the matter to qualify them to sustain the application before this court".

The court went further to hold that the remedies of certiorari and prohibition were not restricted by the notion of locus standi; and every citizen has the capacity to invite the court to prevent some abuse of power, and in so doing, he might claim to be regarded not as a meddlesome busybody but a public benefactor. In 2015-2016, the courts in Republic v. High Court Human Rights, Ex Parte Naa Otua Swyne, Interested Party Prince Kofi Amoabeng posited that supervisory jurisdiction of the courts must not be limited to persons specifically with direct interests in the case upon which the review application was made. This saw a tremendous progress in the legal jurisprudence of the Court as opposed to the Date-Bah's 2003-2004 era jurisprudence. In the above case, as the applicant was the sole complainant who had indeed given evidence before the trial Circuit Court, the courts held that she had more than sufficient interest to protect than anybody else. The courts positioned that it is the duty of every citizen that justice must be seen to be done to all manner of persons by ensuring that the courts in this country established by statutes with limited jurisdiction observe the law within the statutory limits. The jurisprudence went notably further for determination in the 2016-2017 legal year with Republic v. High Court; Ex-parte Charge D'Affairs, Bulgarian Embassy where the courts held that capacity to invoke the supervisory jurisdiction of the Supreme court, article 132, is closely hinged on article 2(1) and as such it scopes public interest law. This position traverses the Professor Date-Bah's 2003-2004 pronouncement and the 2010-2011 position of the courts. It further was pronounced in the 2017-2018 legal year in The Republic v. High Court, Winneba; Ex-parte University Teachers Association of Ghana (UTAG)-Winneba Chapter, And Supi Kofi Kwayera and 2 Others (Interested Parties). The courts unequivocally trumpeted:

"This Court has held repeatedly that applications for prerogative writs have a special public aspect to them and are therefore not restricted by notions of locus standi, i.e. one does not need to show that some legal right is at stake. They may be granted to a total stranger. Our opinion is that since the issues in this application are in respect of the proper administration of justice in conformity with the rules of court, a stranger to the proceedings in the High Court and an incorporated group of persons would have capacity to raise them since it is in the interest of the public that the machinery of the administration of justice works properly".

The above pronouncement can be seen to further uphold the 1991-1992 and 2005-2006 positions relegating the 2003-2004 Professor Date-Bah, most respect- 
fully whose student we two are, and the 2010-2011 legal year's as we thought, to an abyss of judicial hell burning with brimstone and fire as the jurisprudence seem to historically favour a close relationship between article 132 to article 2(1). In furtherance, the 2018-2019 legal year again saw Republic v High Court, Winneba Ex Parte Professor Avoke. The courts again deviated from the strict position in 2003-2004 as seen also in 2010-2011 legal year [supra] to further entrench the long standing position of the courts held earlier in the 1991-1992 and 2005-2006 legal years. The court pronounced that:

"The issue of capacity with regard to the role of a stranger to a judgment, ruling or decision in judicial review applications, particularly with regard to prohibition and certiorari, has been over flogged in this Court and given final judicial blessing. The authorities are legion that the remedies of certiorari and prohibition are not restricted by the notion of locus standi and that every citizen of the land has a standing to invite the Court to prevent some abuse of power. There is no need for such an applicant to show a personal interest or grievance in the matter brought for consideration. The only criterion is that the public must be interested in the matter."

\section{The Sudden Turnaround on February 12, 2020 in Exparte John Bondzie Sey}

The world of legal research with interests in Ghanaian jurisprudence hath noted sharp return in the position of the Supreme Court of Ghana on the issue of capacity to invoke the supervisory jurisdiction of the Court under article 132 to the 2010-2011 and 2003-2004 legal year's despite an avalanche of good judicial reasoning in the tall list of those opposed to the interpretation of the scope of article 132 with limited scope thus backstabbing interests of public interest litigation or intermeddlers aid to justice delivery in Ghana. Just when the world of legal constructive liberalism was taking root within the Ghanaian legal system, the Supreme Court reversed the longest enduring positions of the 1992-1992, 2005-2006, 2016-2017 as well as 2018-2019 that held high third party rights to invoke the supervisory jurisdiction of the Supreme Court in a matter that does not inure any direct benefits to applicant. The Court in the above case mysteriously returned a restrictive grant of capacity under article 132 to the 2003-2004 and 2011-2012 legal years' position. It rather unfortunately, with all respects, held that:

"... the dangerous phenomenon which is creeping into our jurisprudence where other third parties invoke the jurisdiction of this court seeking same reliefs which either this court has refused in an earlier application, or seeking to quash a decision of the High Court in similar applications in which they were not parties must be quickly stopped before it gains roots which will make it difficult to be uprooted".

The court in its concluding judgment, Epilogue, stated thus:

"There is a growing phenomenon which is creeping into the practice of the 
invocation of the supervisory jurisdiction of the Supreme Court, which if not checked and nipped in the bud will add dangerous dimensions to the scope and remit of the parameters of this court in respect of its supervisory jurisdiction. Article 132 of the Constitution 1992, which deals with the supervisory jurisdiction of the Supreme Court provides as follows: The Supreme Court shall have supervisory jurisdiction over all courts and over any adjudicating authority and may, in the exercise of that supervisory jurisdiction, issue orders and directions for the purpose of enforcing or securing the enforcement of its supervisory power."

The implication of the above pronouncement is that, third parties can no longer assume capacity to invoke the Supervisory jurisdiction of the Supreme Court of Ghana in the enforcement of the law such as fundamental human rights through the judicial review tool. This should rather unfortunately, respectfully, be seen as a limitation on the development of the Ghanaian jurisprudence and a stumbling block on legal activism, a crucial aid to the development of law in modern jurisdictions. Is it not only for good that the people would develop interest participation in the justice system, a resort to the courts rather than the growing exercise of the desires for justice on the streets by unapproved courts of street lawyers and judges, unknown to the legal profession just as could be seen in the July, 2020 broad day murder of the 90 year old woman believed to have been in the practice of witchcraft? This is just the most important question, possibly, that anyone with keen interest in the development of the law of Ghana could ask.

Reference can also be given to Order 55 of rule (1) a, b and c of the High Court (Civil Procedure) Rules 2004, C.I. 47 referred to supra, is the premise for of the power of the High Court's supervisory jurisdiction. For academic purposes, we shall lay further the discussions made by the courts in regarding the circumstance of grant of prerogative writs. The parameters for the grant of prerogative writs, Certiorari, prohibition, and mandamus as laid down by the Supreme court in Republic v. High Court, Kumasi, Ex-parte Bank of Ghana and Others, (Sefa and Asiedu-Interested Parties) (No. 1) Republic v High Court, Kumasi, EX-parte Bank of Ghana and Others (Gyamfi and Others Interested Parties No. 1) Consolidated are;

1) Availability of alternative effective remedies such as (i) appeals (ii) application to set aside the proceedings sought to be impugned.

2) The conduct of the applicant and in some cases, conduct of Counsel for the applicant which may be found to be reprehensible and therefore underserving of the grant of the courts discretion in their favour.

That means that any action on the case regarding issues of procedural law, as to how an administrative body or tribunal, through judicial review has arrived at a decision must be commenced in the High Court. Grant of capacity under the long standing regimes of the 1991-1992, 2005-2006, 2017-2018 and 2018-2019 [supra] which allows interlopers to fall under article 132 of the Constitution to 
invoke the Supervisory jurisdiction of the Supreme Court does not mean automatic grant of the writs as the order for Prerogative writs are at the discretion of the courts, when satisfied that such intermeddler acts as surrogate of another in outwitting procedural laws, the courts would refuse the application under policy interests. That was the informing reason, inter alia, for the courts refusing the issue of certiorari to John Bondzie Sey, the applicant in the REPUBLIC v HGH COURT CAPE COAST; EXPARTE JOHN BONDZIE SEY; INTERESTED PARTY UNIVERSITY OF EDUCATION WINNEBA.

\section{Reasoning in Favour of Third-Party Rights to Supervisory Jurisdiction of the Supreme Court of Ghana}

Democracy is evolving, so the need for all institutions of state to make development an agenda for the realization of the collective vision of the forbearers of our country, the West African region, Continental Africa and the World at large, so is the need of the courts of our time who sit in arguably the most peaceful era of the many turbulent history of our beautiful country, Ghana. It must be noted that, recognition of rights is a thing noted with stable democracies, thus the fearless resort to the courts in citizenry participation in the discourse of justice dissemination. Highlights can be drawn from the inaugural speech of the fifth President of the Republic of Ghana under the 1992 Constitutional era where emphatic employs were made to Ghanaians to be CITIZENS NOT SPECTATORS. In fulfilment of this democratic wish, institutions of state must be willing to provide enough room for citizens and allow citizen participation in shaping the public discourse. In the sphere of justice delivery, legal activism must be allowed therefore to fester to save the excesses of the courts and state institutions within the Ghanaian legal system. In the Naa Otua Swyne Case, it took the intervention of an intermeddler, the complainant, to ensure justice. The Supreme Court held that:

"We also have to place on record the conduct of the office of the Attorney General in these proceedings. It appears that lip service was paid to the application at the High Court where the Circuit Court's proceedings was quashed and same prohibited from further hearing of the criminal case. It took the active intervention of the complainant (the applicant herein) to mount this application at this court to quash the ruling of the High Court." In Gyimah v. Abrokwah, the Supreme Court condemned counsel who ignored the avowed duty as officer of the court and noted that, should the intermeddler not have applied to the court, the traverses of the High Court would not have been corrected. The exact words were that:

"If the applicant had not mounted this application, the Attorney General's office who were indeed served with the processes from the High Court [Human Rights] Division, Accra, wouldn't have questioned the orders made by the learned High Court judge, which orders had no legal basis whatsoever."

The Court still on the relevance of an intermeddler in the Ghanaian justice 
system in Republic v High Court Human Right, Naa Otua Swyne, Interested Party Prince Kofi Amoabeng went on to commend the intermeddler for her timeous intervention and awarded costs but directed it against the counsel for the first interested party. Notice must be given to progressive posture of the Supreme Court in the enforcement of fundamental human rights by third parties at the Supreme Court. The enforcement of fundamental human rights at the Supreme Court requires that, one does not need to have personal interest affected to institute an action in enforcement of fundamental human rights under Chapter five (5) of the 1992 Constitution. It is our fervent prayer that such warm reception granted to strangers when enforcing Chapter Five Provisions of the Constitution, 1992 under Public Interest Litigation would be accorded to interlopers when the Court's jurisdiction is invoked under Article 132 of the Constitution.

\section{Recommendation and Conclusion}

In summary, the Supreme Court of Ghana has over the legal years thus 2003-2004, 2011-2012 and 2019-2020 held that persons with direct interest in issues before the courts are clothed with capacity to invoke the supervisory jurisdiction of the Supreme Court of Ghana in requesting actions from same, directed against the decision of those courts. The Supreme Court likewise has over the years; 1991-1992, 2005-2006, 2017-2018 and 2018-2019 ruled that in accessing its Supervisory role over all other courts in Ghana, said that person must assume capacity to invoke same under the general principles of public interest protection. That having been said, has led to grave unpredictability in the Ghanaian. As legal reform advocates and researchers, we will lend our voice once more to the Rules of Court Committee to quickly arrest this confusion through reform of the rules of procedure, High Court Civil (Procedure) Rules and the Supreme Court Rules with explicit rules on capacity for Article 132. This will complement efforts made in other jurisdictions towards the growth of regional jurisprudence. We recommend that these rules should allow third party, intermeddler participation without limitations to ensure public participation in justice delivery, a recipe for development of our laws and society. Legal technicalities and strictness should not be a guide to justice dispensation within the Ghanaian legal system and methods.

\section{Conflicts of Interest}

The authors declare no conflicts of interest regarding the publication of this paper.

\section{References}

1992 Constitution of the Republic of Ghana: Articles 132, 2 Clause 1, 140 and Chapter 5.

Barrett, A. C. (2006). The Supervisory Power of the Supreme Court. Columbia Law Review, 106, 324. 
Brown v. Quashigah [2003-2004] SCGLR at 941. https://www.ghalii.org

https://www.judy.legal/

Dickerson v. United States, 530 U.S. 428, 437(2000).

Gyimah v. Abrokwah [2011] 1 SCGLR 406. https://www.ghalii.org https://www.judy.legal/

Kumado, C. K. (1977). Constitutionalism, Civil Liberties and Development. https://escholarship.org/uc/item/1df0c35b

Odike, E., \& Akujobi, A. (2018). Enforcement of Fundamental Rights in National Constitutions: Resolving the Conflict of Jurisdiction between the Federal High Court and State High Court in Nigeria. Beijing Law Review, 9, 53-66.

Order 55 of Rule (1) a, b and c of the High Court (Civil Procedure) Rules 2004, C.I. 47.

Republic v. Committee of Inquiry into Nungua Traditional Council Affairs; Exparte Odai IV [1996-97] SCGLR 401. https://www.ghalii.org

https://www.judy.legal/

Republic v. High Court Human Rights; Ex Parte Naa Otua Swyne; Interested Party Prince Kofi Amoabeng Civil Motion № J5/8/2015. https://www.ghalii.org https://www.judy.legal/

Republic v. High Court, Accra; Ex Parte Appenteng [1991] IGLR 353CA. https://www.ghalii.org https://www.judy.legal/

Republic v. High Court, Denu; Ex Parte: Agbesi Awusu Ii (No 1), (Nyonyo Agboada (Sri Iii) Interested Party) Holding 2, Page 867. https://www.ghalii.org https://www.judy.legal/

Republic v. High Court, Ex-Parte Sosu [1996-97] 2 SCGLR 525. https://www.ghalii.org https://www.judy.legal/

Republic v. High Court, Ho, Ex Parte Bediako Li \& Anor (Odum \& Ors Interested Parties Suit No. J5/45/2018. https://www.ghalii.org https://www.judy.legal/

Republic v. High Court, Kumasi, Ex-parte Bank of Ghana and Others, (Sefa and Asiedu-Interested Parties) (No. 1) Republic v High Court, Kumasi, Ex-parte Bank of Ghana and Others (Gyamfi and Others Interested Parties No. 1) Consolidated. https://www.ghalii.org https://www.judy.legal/

Republic v. High Court, Kumasi; Ex Parte Appiah and Others [1997-98] 1 GLR 503. https://www.ghalii.org https://www.judy.legal/

Republic v. High Court, Kumasi; Ex-Parte Bank of Ghana (No. 1) [2013-2014] 1SCGLR 477. https://www.ghalii.org https://www.judy.legal/

Republic v. High Court; Ex-parte Charge D’Affairs, Bulgarian Embassy No. J5/34/2015. https://www.ghalii.org https://www.judy.legal/

Republic v. Korle Gonno District Magistrate Grade I; Ex Parte Ampomah [1991] IGLR $353 C A$. https://www.ghalii.org https://www.judy.legal/

State v. Asantehene's Divisional Court BI; Ex Parte Kusada [1963] 2 GLR 238. https://www.ghalii.org https://www.judy.legal/ 
The Republic v. Court Of Appeal; EX-Parte Tsatsu Tsikata [2005-2006] SCGLR 612. https://www.ghalii.org https://www.judy.legal/

The Republic v. High Court, Accra; Ex-Parte CHRAJ (Addo Interested Party) [2003-2004] SCGLR 312. https://www.ghalii.org https://www.judy.legal/

The Republic v. High Court, General Jurisdiction; Ex Parte Attorney General; Interested Party Exton Cubic [2020] GHASC 9. https://www.ghalii.org https://www.judy.legal/

The Republic v. High Court, Winneba; Ex-parte University Teachers Association of Ghana (UTAG)-Winneba Chapter; and Supi Kofi Kwayera and 2 Others (Interested Parties) Suit No J5/65/2017. https://www.ghalii.org

https://www.judy.legal/ 